\title{
Respiratory health of workers exposed to low levels of chromium in stainless steel production
}

Markku Huvinen, Jukka Uitti, Anders Zitting, Pekka Roto, Kristina Virkola, Pertti Kuikka, Pekka Laippala, Antero Aitio

\begin{abstract}
Objectives-To determine whether occupational exposure to chromite, trivalent chromium, or hexavalent chromium causes respiratory diseases, an excess of respiratory symptoms, a decrease in pulmonary function, or signs of pneumoconiosis among workers in an integrated chain of stainless steel production.

Methods-This cross sectional study was carried out in 1993 and the inclusion criterion was a minimum of eight years of employment in the same production department. A self administered questionnaire was collected, and spirometry, measurement of diffusing capacity, chest radiography, and laboratory tests were carried out by a mobile research unit.
\end{abstract}

Results-There were 221 workers in the exposure groups and 95 in the control group. The average duration of employment was 18 years. No significant differences in the odds ratios (ORs) of the symptoms were found between the exposure and the control groups. In a logistic regression analysis age and smoking significantly explained the occurrence of most of the respiratory symptoms. The smokers in the chromite group had significantly lower forced vital capacity (FVC), forced expiratory volume in one second $\left(F E V_{1}\right)$, and diffusing capacity than the corresponding values of the control group. The analysis of variance between study groups, smoking, and exposure time, without modelling for interactions, showed that the chromite group had lower values for FVC, $F_{E V}$, and diffusing capacity than the other groups. The occurrence of small opacities was more frequent on the chest radiographs of the workers in the chromite group.

Conclusions-An average exposure time of 18 years in ferrochromium and stainless steel production and exposure to dusts containing low concentrations of hexavalent or trivalent chromium do not lead to any respiratory changes detectable by lung function tests or radiography nor to any increase in symptoms of respiratory diseases. The lung function values were lower and the occurrence of radiological findings was more frequent among the workers from the chromite mine than among the controls. The difference was partly caused by differences in age and smoking habits, but evidently also partly by higher exposures more than two decades ago or by the fibrous components of the dust.

(Occup Environ Med 1996;53:741-747)

Keywords: stainless steel production; chromium exposure; respiratory health

Chromate dust and fumes of chromium trioxide have been reported to cause asthma. ${ }^{1}$ Chromates, among other exposure agents in chromium plating, welding, and ferrochromium production, have been connected with cases of occupational asthma ${ }^{2}$ or bronchitis. Mining dust in an underground chromite ore mine has also been reported to cause chronic bronchitis. ${ }^{3}$

Obstructive effects on lung function have also been found among chromium workers. ${ }^{4-6}$ In one study reduced forced vital capacity (FVC) and an increased prevalence of obstructive lung diseases were found among electrofurnace workers in a ferrochromium plant. ${ }^{7}$ The author suggested that the effects were due to high levels of total dust, especially amorphous silica dust.

Nodular pneumoconiosis is another finding among workers in chromate production. ${ }^{8} 9$ However, it has not been confirmed in some studies. ${ }^{710}$ In a study on respiratory symptoms among 60 ferrochromium workers in Norway pneumoconiosis was diagnosed from the radiographical examinations.?

The integrated production chain of Outokumpu Steel Oy is unique; the mine and all the stainless steel manufacturing plants are in the same region. The figure shows a flow chart of the process. Unlike the rest of the ferrochromium furnaces in the world, the Outokumpu process is a fully closed system.

In an animal experiment ${ }^{11}$ chromite particles from Outokumpu's chromium mine were considered to be fibrogenetically inert.

The purpose of the present study was to determine whether long term occupational exposure to low levels of chromite, trivalent chromium $\left(\mathrm{Cr}^{+3}\right)$, or hexavalent chromium $\left(\mathrm{Cr}^{+6}\right)$ causes respiratory diseases, an excess of respiratory symptoms, a decrease in pulmonary function, or signs of pneumoconiosis among workers in an integrated chain of stainless steel production, and to investigate whether $\mathrm{Cr}^{+3}$ and $\mathrm{Cr}^{+6}$ compounds (known to differ in their toxicity) also differ from each other in this respect. 


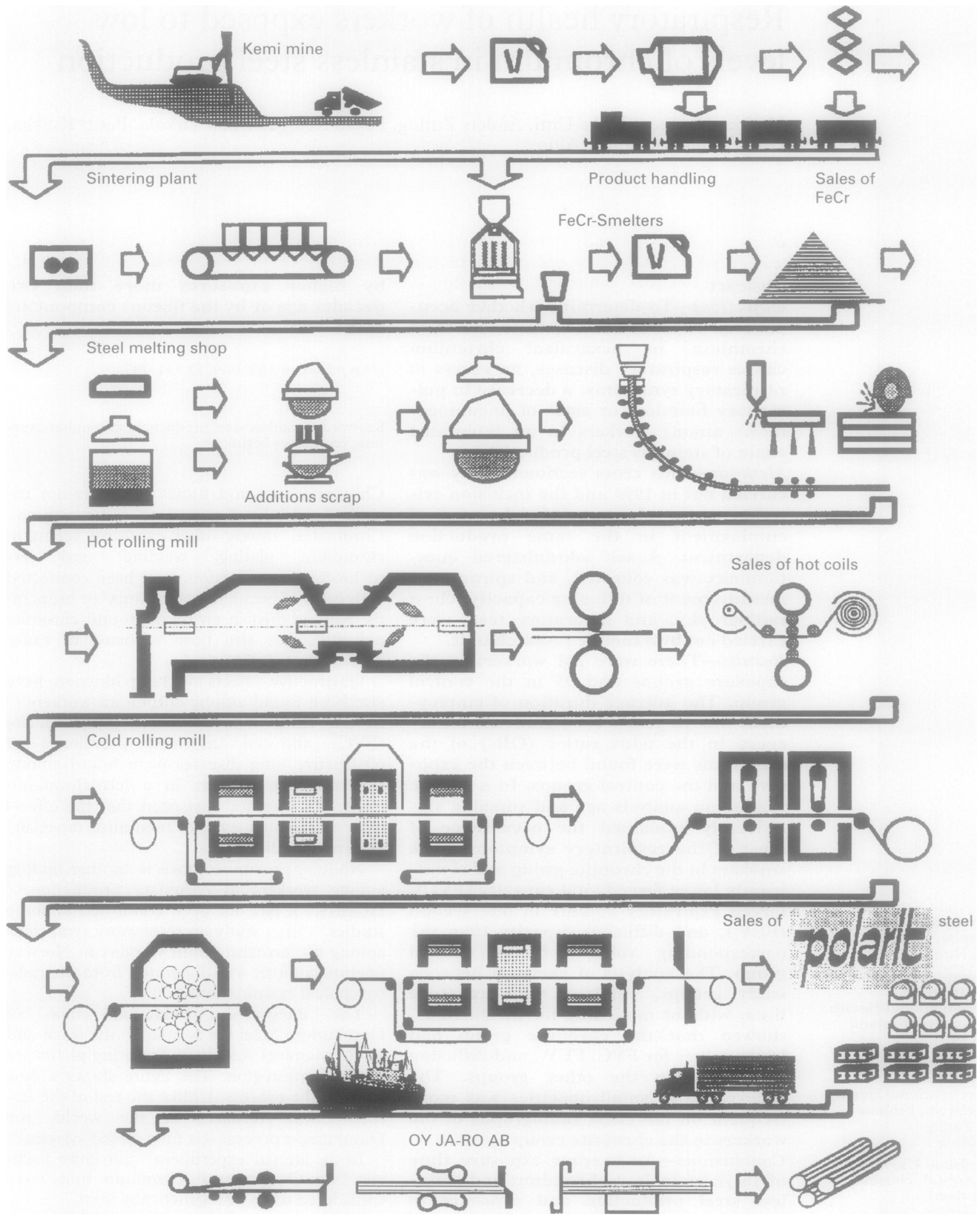

Flow chart of the production chain.

\section{Subjects and methods}

SUBJECTS

At the time of the study, from March to May 1993, there were 892 workers in the production departments. The subjects were divided into four groups according to exposure to different chromium compounds: exposure to $\mathrm{Cr}^{+6}, \mathrm{Cr}^{+3}$, chromite, and a control group. In this study the inclusion criterion was a mini- mum of eight years of employment in the same department. Altogether 222 workers met the criteria of exposure and duration of employment and were placed in one of the three exposure groups. One of the workers did not agree to participate in the study. The control group consisted of workers from the cold rolling mill (the Sendzimir rolling mill, the skin pass mill, and the splitting and cutting 
line), because their level of exposure to chromium or dust in general was extremely low-or non-existent. Out of the 132 potential controls, 95 agreed to participate. The lower response rate among controls was mainly due to the relative inconvenience to the workers in matching workshifts with study appointments. The total number of subjects was therefore 316 and all of them were men with similar ethnic and socioeconomic backgrounds.

The company also provided a list of names of the workers who had been working for at least eight years in any of the production departments under study and then resigned. There were 53 such workers; 17 of them had been exposed to $\mathrm{Cr}^{+6}$, four to $\mathrm{Cr}^{+3}$, and 19 to chromite; 13 of them had been working in the cold rolling mill where the control group worked. A questionnaire was sent to all of these former workers, but no clinical examinations were made.

\section{EXPOSURE}

An exposure study was carried out through the whole production chain in $1987 . .^{12}$ At the chromite mine in Kemi (chromite group) the average dust concentration was $1 \mathrm{mg} / \mathrm{m}^{3}$. The median personal exposure to chromium was $22 \mu \mathrm{g} / \mathrm{m}^{3} ; \mathrm{Cr}^{+6}$ was not detected in any of the samples.

In the furnace department of the ferrochromium plant $\left(\mathrm{Cr}^{+6}\right.$ group) the average dust exposure was $1.5 \mathrm{mg} / \mathrm{m}^{3}$. The dust contained an average of $5 \%-10 \%$ chromium. The proportion of $\mathrm{Cr}^{+6}$ of the total chromium was $0 \cdot 1 \%-0 \cdot 3 \%$. The highest concentrations were detected during tapping in the vicinity of the tap hole, where the proportion of $\mathrm{Cr}^{+6}$ was 10 fold $(1 \%-3 \%)$ the level in other areas. In the sintering and crushing departments $\left(\mathrm{Cr}^{+3}\right.$ group) the average dust exposure was $2 \cdot 4 \mathrm{mg} / \mathrm{m}^{3}$.

In the steel smelting shop $\left(\mathrm{Cr}^{+6}\right.$ group), the average exposure to total dust was $1.8 \mathrm{mg} / \mathrm{m}^{3}$. The dust contained $2 \%-4 \%$ chromium. The median $\mathrm{Cr}^{+6}$ concentration was $0.5 \mu \mathrm{g} / \mathrm{m}^{3}$. The highest values among personal samples were detected in the handling of molten metal by the arc furnace $\left(6 \cdot 6 \mu \mathrm{g} / \mathrm{m}^{3}\right)$. Although judged from the stationary samples (in which the amount of air collected was large), $\mathrm{Cr}^{+6}$ seemed to be present at low concentrations throughout the steel smelting shop; it exceeded the detection limit of $0.5 \mu \mathrm{g} / \mathrm{m}^{3}$ in only some of the personal samples.

The total dust content was low throughout the cold rolling mill (control group); it averaged $0.3-0.5 \mathrm{mg} / \mathrm{m}^{3}$. In general, the content of chromium in the air in the cold rolling mill was lower than the detection limit of the measurement method.

\section{METHODS}

A questionnaire was sent to the participants one week before the clinical examinations. It was based on the standardised questionnaire of a study made in the wool textile industry by the Edinburgh Study Group ${ }^{13}$ and the definitions from the Medical Research Council (MRC) questionnaire, ${ }^{14}$ and it asked for infor- mation on personal characteristics, occupational history, respiratory symptoms, smoking habits, medication, and personal and family histories of allergic and pulmonary diseases. Some questions considered, among other things, the following items: cough, phlegm, shortness of breath, and wheeze. Symptoms of rhinitis and eye irritation were also included.

Cough, lasting more than three months and improving after a holiday of more than one week, was considered to be work related. Similarly, dyspnoea occurring at least twice a month and caused or worsened by impurities in the work environment or during a workshift, but becoming better after a week's holiday, was regarded as work related. Questions about back or stomach pain and general health status were used as control questions because they were not considered to be associated with the current occupational exposure.

Spirometry, measurement of diffusing capacity, a chest $x$ ray film examination, and laboratory tests were carried out by a mobile research unit with two experienced laboratory technicians.

Spirometry was performed on each subject with a computerised flow volume spirometer ME 101 (Medikro Oy, Kuopio, Finland). The spirometer was calibrated each day with a 5 litre syringe. At least three satisfactory acceptable forced maximal expirations were performed according to the standards of the American Thoracic Society, ${ }^{15}$ and all volumes were corrected to body temperature, pressure, and saturation (BTPS). Each subject was seated wearing a nose clip. From the maximum expiratory flow volume curves the highest FVC, forced expiratory volume in one second $\left(\mathrm{FEV}_{1}\right)$, and flow rates at $50 \%$ and $25 \%$ of the vital capacity $\left(\mathrm{MEF}_{50}, \mathrm{MEF}_{25}\right)$ and their mean flow (MMEF) were read.

All of the values were also expressed as percentages of predicted values in Finland. ${ }^{16}$ Two trained laboratory technicians examined an equal number of people. The technicians' performance of spirometry was compared before the study. The mean difference in the FVC of the people tested was minimal $(2 \cdot 1 \%)$.

Diffusing capacity of the lungs for carbon monoxide (TLCO) was measured with the Morgan transfer test and the single breath method. Alveolar volume $\left(\mathrm{V}_{\mathrm{A}}\right)$ is the total lung capacity found at the time when the TLCO is measured. The specific diffusing capacity is TLCO/VA. The same laboratory technician performed at least two successful consecutive measurements for each person; the mean value of the two nearest test results was chosen. ${ }^{17}$ These values were adjusted to the real time haemoglobin measurement. ${ }^{18}$ The results were also expressed as percentages of predicted values in Finland. ${ }^{16}$

In the radiographic examination full size $35 \times 43 \mathrm{~cm} x$ ray films were used. The radiographs were classified according to the modified classification system of International Labour Organisation (ILO). ${ }^{19}$

Two radiologists, both of whom were experienced with the ILO system, classified the radiographs individually without knowing the 
Table 1 Characteristics of the study groups

\begin{tabular}{|c|c|c|c|c|}
\hline Characteristic & $\begin{array}{l}C r^{+6} \text { group } \\
(n=109)\end{array}$ & $\begin{array}{l}C r^{+3} \text { group } \\
(n=76)\end{array}$ & $\begin{array}{l}\text { Chromite group } \\
(n=36)\end{array}$ & $\begin{array}{l}\text { Control group } \\
(n=95)\end{array}$ \\
\hline \multicolumn{5}{|l|}{ Age (y): } \\
\hline Mean (SD) & $43 \cdot 3(6 \cdot 9)$ & $45 \cdot 5(6 \cdot 8)$ & $44 \cdot 6(7 \cdot 6)$ & $40 \cdot 7(7 \cdot 1)$ \\
\hline $\begin{array}{c}\text { Range } \\
\text { Height }(\mathrm{cm})\end{array}$ & $29-59$ & $29-60$ & $30-63$ & $30-64$ \\
\hline Mean (SD) & $174 \cdot 6(5 \cdot 9)$ & $174 \cdot 8(5 \cdot 2)$ & $174 \cdot 1 \cdot 6 \cdot 3)$ & $174 \cdot 3(6 \cdot 9)$ \\
\hline Range & $159-189$ & $163-187$ & $162-190$ & $157-191$ \\
\hline \multicolumn{5}{|l|}{ Weight (kg): } \\
\hline Mean (SD) & $89.9(10 \cdot 7)$ & $81 \cdot 0(11 \cdot 2)$ & $79.1(13.5)$ & $80 \cdot 0(11 \cdot 8)$ \\
\hline Range & $61-110$ & $57-108$ & $54-117$ & $61-140$ \\
\hline \multicolumn{5}{|l|}{ Work history $(\mathrm{y})$ : } \\
\hline Mean (SD) & $16 \cdot 0(4 \cdot 6)$ & $20 \cdot 8(4 \cdot 5)$ & $19 \cdot 5(5 \cdot 6)$ & $14 \cdot 4(2 \cdot 7)$ \\
\hline Range & $8-26$ & $9-27$ & $9-27$ & $8-18$ \\
\hline \multicolumn{5}{|l|}{ Smoking status (\%): } \\
\hline Non-smoker & $37 \cdot 6$ & $29 \cdot 3$ & $16 \cdot 7$ & $35 \cdot 1$ \\
\hline Ex-smoker & $33 \cdot 4$ & $32 \cdot 0$ & $25 \cdot 0$ & $19 \cdot 2$ \\
\hline Current smoker & $28 \cdot 4$ & $38 \cdot 7$ & $58 \cdot 3$ & $45 \cdot 7$ \\
\hline \multicolumn{5}{|l|}{ Present smoking: } \\
\hline $\begin{array}{c}\text { Cigarettes/day: } \\
\text { Mean (SD) }\end{array}$ & $16 \cdot 7(6 \cdot 5)$ & $16.9(5.4)$ & $17 \cdot 0(5 \cdot 4)$ & $15 \cdot 1(7 \cdot 2)$ \\
\hline \multicolumn{5}{|l|}{$\begin{array}{l}\text { Total duration of } \\
\text { smoking }(y) \text { : }\end{array}$} \\
\hline Mean (SD) & $16 \cdot 3(7 \cdot 9)$ & $18.9(9 \cdot 3)$ & $20 \cdot 1(8 \cdot 3)$ & $17 \cdot 4(8 \cdot 3)$ \\
\hline
\end{tabular}

names or exposure data of the subjects. If the classifications of the radiologists differed, the higher classification was recorded as the result One of the radiologists was a certified NIOSH $B$ reader. The radiographs of the control group were mixed with those of the exposed groups.

The urinary concentration of chromium was measured from the specimens of 44 workers from the steel smelting shop to ascertain the exposure level compared with the level in an earlier study in the same production chain. ${ }^{12}$ Every other worker in the steel smelting shop was selected from the alphabetical payroll list. The specimens were collected in the afternoon after the workshift.

Table 2 Prevalence of symptoms*

\begin{tabular}{|c|c|c|c|c|}
\hline Symptom & $\begin{array}{l}C r^{+6} \text { group } \\
(n=109) \\
\%\end{array}$ & $\begin{array}{l}\mathrm{Cr}^{+3} \text { group } \\
(n=76) \\
\%\end{array}$ & $\begin{array}{l}\text { Chromite group } \\
(n=36) \\
\%\end{array}$ & $\begin{array}{l}\text { Control group } \\
(n=95) \\
\%\end{array}$ \\
\hline Cough $>3 / 12$ months & $10 \cdot 4$ & $21 \cdot 1$ & $19 \cdot 4$ & $10 \cdot 5$ \\
\hline Work related cough & 5.5 & $9.2 \mathrm{P}=0.01$ & $2 \cdot 8$ & $1 \cdot 1$ \\
\hline Phlegm > 3/12 months & $18 \cdot 5$ & $26.7 \mathrm{P}=0.01$ & $25.0 \mathrm{P}=0.04$ & $10 \cdot 6$ \\
\hline \multirow{5}{*}{$\begin{array}{l}\text { Shortness of breath } \\
\text { (and wheezing) } \\
\text { Work related cough or } \\
\text { shortness of breath } \\
\text { Breathlessness on exertion } \dagger \\
\text { Rhinitis }>3 / 12 \text { months }\end{array}$} & $8 \cdot 3$ & $14 \cdot 5$ & $11 \cdot 1$ & $6 \cdot 3$ \\
\hline & & & & \\
\hline & $11.9 P=0.04$ & $13.2 P=0.03$ & $5 \cdot 6$ & $4 \cdot 2$ \\
\hline & $11 \cdot 0$ & $19.7 P=0.03$ & 13.9 & $8 \cdot 4$ \\
\hline \multirow{2}{*}{\multicolumn{5}{|c|}{ Eye symptoms }} \\
\hline & & & & \\
\hline$>3 / 12$ months & $17 \cdot 8$ & $17 \cdot 3$ & $5 \cdot 6$ & $11 \cdot 6$ \\
\hline Abdominal pain & $50 \cdot 0$ & $41 \cdot 1$ & $25 \cdot 0$ & $36 \cdot 6$ \\
\hline Back pain & $64 \cdot 5$ & $65 \cdot 8$ & $50 \cdot 0$ & $60 \cdot 2$ \\
\hline \multicolumn{5}{|l|}{ Health condition: } \\
\hline Good & $43 \cdot 1$ & $48 \cdot 7$ & $52 \cdot 8$ & $60.0 P=0.02$ \\
\hline $\begin{array}{l}\text { Average } \\
\text { Poor }\end{array}$ & $49.5 \mathrm{P}=0.05$ & $38 \cdot 2$ & $36 \cdot 1$ & $35 \cdot 8$ \\
\hline Poor & $7 \cdot 3$ & $13 \cdot 2 \mathrm{P}$ & $8 \cdot 3$ & $4 \cdot 2$ \\
\hline
\end{tabular}

${ }^{\star} \mathrm{Cr}{ }^{*}, \mathrm{Cr}^{+3}$, and chromite groups $v$ control group, Student's two tailed $t$ test.

†Shortness of breath when hurrying on level ground.

Table 3 Logistic regression analysis of respiratory symptoms

\begin{tabular}{|c|c|c|c|}
\hline Symptom & $\begin{array}{l}C r^{+6} \text { group } \\
(n=109) \\
O R^{\star}(95 \% C I)\end{array}$ & $\begin{array}{l}C r^{+3} \text { group } \\
(n=76) \\
O R^{*}(95 \% C I)\end{array}$ & $\begin{array}{l}\text { Chromite group } \\
(n=36) \\
O R^{\star}(95 \% C I)\end{array}$ \\
\hline $\begin{array}{l}\text { Cough }>3 / 12 \text { months } \\
\text { Phlegm }>3 / 12 \text { months } \\
\text { Shortness of breath } \\
\text { Chest tightness } \\
\text { Breathlessness on exertion } \dagger \\
\text { Rhinitis }\end{array}$ & $\begin{array}{l}1.12(0.43-2.92) \\
2.18(0.80-5.92) \\
1.55(0.49-4.91) \\
1.19(0.53-2.65) \\
1.25(0.44-3.53) \\
1.02(0.49-2.12)\end{array}$ & $\begin{array}{l}1 \cdot 61(0.54-4 \cdot 81) \\
2 \cdot 17(0 \cdot 70-6 \cdot 76) \\
2 \cdot 77(0 \cdot 76-10 \cdot 08) \\
1.39(0.53-3 \cdot 62) \\
1.92(0.57-6.43) \\
2 \cdot 22(0.92-5.33)\end{array}$ & $\begin{array}{l}1.22(0.36-4.09) \\
1.26(0.37-4.31) \\
1.82(0.42-7.94) \\
1.24(0.41-3.74) \\
0.96(0.23-3.91) \\
1.43(0.49-4.18)\end{array}$ \\
\hline Any of these symptoms & $1.39(0 \cdot 70-2 \cdot 80)$ & $2 \cdot 11(0.92-4 \cdot 83)$ & $1.11(0.42-2.92)$ \\
\hline
\end{tabular}

*Age and duration of exposure as continuous variables and earlier pulmonary diseases as classified variables.

†Shortness of breath when hurrying on level ground.

\section{STATISTICAL METHODS}

Basic statistics were used to describe the data. The frequency tables were analysed with $\chi^{2}$ statistics. The multivariate analysis was based on logistic regression analysis, where we have included possible confounders as predictors and their effect was adjusted, when needed. The effect of risk factors in the model were shown with adjusted odds ratios. The natural confounders in our study were age, exposure time, smoking, earlier lung disorders, and atopic diseases. When the relation between pulmonary functions and exposure were studied, we used Student's $t$ test and analysis on covariate. Here the possible effect of confounders was taken into account using covariates. The possible confounders were age, exposure time, height, weight, and smoking. As a covariate, smoking was taken into the model as pack-years, but we also included it in the model as a factor, where it was classified. The statistical software used was SAS (SAS Institute, USA) and Egret (Egret, USA).

\section{Results}

SUBJECTS

The participation of exposed workers in this study was high, almost $100 \%$, and for the controls the corresponding value was $72 \%$.

The study groups were similar in height and weight (table 1). There was a five year difference between the mean age of the youngest (control) and the oldest $\left(\mathrm{Cr}^{+3}\right)$ groups. More than half of the workers in the $\mathrm{Cr}^{+3}$ and chromite groups were between the ages of 45 and 65 years. The chromite group contained more current smokers and fewer non-smokers than the other groups. Also, the chromite group smoked more and had smoked longer than the other groups.

Only three men had been previously exposed to chromium compounds in the metal industry. The groups were similar for former agricultural work and exposures to silica dust, welding fumes, asbestos, solvents, and textile dusts (data not shown). There were no differences between the number of reported earlier allergic or pulmonary diseases diagnosed by a physician. Allergic rhinitis and bronchial asthma were infrequent; no asthma was reported in the chromite or control group. The groups were similar with regard to medication for hypertension and cardiovascular diseases.

\section{SYMPTOMS}

The prevalence of most of the respiratory and other symptoms did not differ significantly in the comparison between the groups (table 2). The production of phlegm was more frequent in the $\mathrm{Cr}^{+3}$ and chromite groups than in the other groups. Work related cough or dyspnoea was significantly more frequent in the $\mathrm{Cr}^{+6}(\mathrm{P}$ $=0.041)$ and the $\mathrm{Cr}^{+3}(\mathrm{P}=0.033)$ groups than in the control group.

No significant differences between the exposure groups and the controls were found in the odds ratio (OR) of the symptoms (table 3 ). In the logistic regression analysis age and smoking significantly explained the occurrence 
Table 4 Lung function measurements as a percentage of predicted values*

\begin{tabular}{|c|c|c|c|c|c|c|c|c|}
\hline \multirow[b]{2}{*}{$\begin{array}{l}\text { Lung } \\
\text { function } \\
\text { variable }\end{array}$} & \multicolumn{2}{|l|}{$\mathrm{Cr}^{+6}$ group } & \multicolumn{2}{|l|}{$\mathrm{Cr}^{+3}$ group } & \multicolumn{2}{|l|}{ Chromite group } & \multicolumn{2}{|l|}{ Control group } \\
\hline & $\begin{array}{l}\text { Non-smokers } \\
(n=41) \\
\text { mean }(S D)\end{array}$ & $\begin{array}{l}\text { Smokerst } \\
(n=67) \\
\text { mean }(S D)\end{array}$ & $\begin{array}{l}\text { Non-smokers } \\
(n=22) \\
\text { mean }(S D)\end{array}$ & $\begin{array}{l}\text { Smokerst } \\
(n=52) \\
\text { mean }(S D)\end{array}$ & $\begin{array}{l}\text { Non-smokers } \\
(n=6) \\
\text { mean }(S D)\end{array}$ & $\begin{array}{l}\text { Smokerst } \\
(n=30) \\
\text { mean }(S D)\end{array}$ & $\begin{array}{l}\text { Non-smokers } \\
(n=33) \\
\text { mean }(S D)\end{array}$ & $\begin{array}{l}\text { Smokerst } \\
(n=60) \\
\text { mean }(S D)\end{array}$ \\
\hline FVC & $96 \cdot 4(11 \cdot 1)$ & $93.5(9.6)$ & $93.8(8.9)$ & $\begin{aligned} & 90.7(10.6) \\
& P<0.05\end{aligned}$ & $93.6(11 \cdot 7)$ & $\begin{array}{l}86.8(10.7) \\
P<0.01\end{array}$ & $93.5(9 \cdot 5)$ & $95 \cdot 2(10 \cdot 4)$ \\
\hline $\mathrm{FEV}_{1}$ & $95 \cdot 5(11 \cdot 4)$ & $91 \cdot 8(12 \cdot 2)$ & $93.8(11 \cdot 6)$ & $89.1(11 \cdot 8)$ & $92 \cdot 1(10 \cdot 9)$ & $\begin{array}{l}83.1(14.8) \\
P<0.01\end{array}$ & $94 \cdot 6(10 \cdot 7)$ & $92 \cdot 7(11 \cdot 8)$ \\
\hline $\begin{array}{l}\text { FEV\% } \\
\text { PEF } \\
\text { MEF }_{50} \\
\text { MEF }_{25} \\
\text { TLCO }\end{array}$ & $\begin{array}{r}99 \cdot 8(6 \cdot 6) \\
102 \cdot 5(11 \cdot 9) \\
95 \cdot 7(21 \cdot 3) \\
86.5(26 \cdot 1) \\
102 \cdot 3(20 \cdot 1)\end{array}$ & $\begin{array}{c}98 \cdot 1(7 \cdot 9) \\
103 \cdot 6(13 \cdot 2) \\
87 \cdot 0(26 \cdot 1) \\
82 \cdot 1(32 \cdot 7) \\
97 \cdot 2(20 \cdot 2)\end{array}$ & $\begin{aligned} 99 \cdot 6(6.9) \\
97.9(18.0) \\
87.8(30.8) \\
83.8(31.4) \\
109.3(16.9)\end{aligned}$ & $\begin{array}{c}98 \cdot 2(7 \cdot 1) \\
100 \cdot 6(14 \cdot 1) \\
83 \cdot 2(25 \cdot 4) \\
81 \cdot 0(27 \cdot 5) \\
90 \cdot 4(18 \cdot 5)\end{array}$ & $\begin{array}{c}98.5(6 \cdot 3) \\
105.6(7 \cdot 9) \\
88.7(18 \cdot 9) \\
82.6(26 \cdot 1) \\
85.5(42 \cdot 6)\end{array}$ & $\begin{array}{l}95 \cdot 2(10 \cdot 3) \\
97 \cdot 7(12 \cdot 9) \\
74 \cdot 7(28 \cdot 3) \\
69 \cdot 1(28 \cdot 8) \\
82 \cdot 1(31 \cdot 4) \\
P<0.05\end{array}$ & $\begin{array}{r}101 \cdot 1(5 \cdot 9) \\
102 \cdot 2(11 \cdot 6) \\
95 \cdot 2(22 \cdot 2) \\
96 \cdot 9(33 \cdot 4) \\
102 \cdot 4(23 \cdot 3)\end{array}$ & $\begin{array}{l}97 \cdot 3(6 \cdot 9) \\
98 \cdot 6(14 \cdot 4) \\
82 \cdot 7(22 \cdot 7) \\
82 \cdot 2(30 \cdot 3) \\
95 \cdot 6(13 \cdot 8)\end{array}$ \\
\hline $\mathrm{TLCO}_{\mathrm{Hb}}$ & $101 \cdot 6(20 \cdot 1)$ & $96.3(19.4)$ & $109.0(15 \cdot 5)$ & $90 \cdot 6(18 \cdot 4)$ & $85 \cdot 6(42 \cdot 6)$ & $\begin{array}{l}81.9(31.2) \\
P<0.05\end{array}$ & $102 \cdot 2(22 \cdot 8)$ & $94 \cdot 3(14 \cdot 0)$ \\
\hline $\begin{array}{l}\text { TlCo/VA } \\
\text { TLCO/VA }_{\mathrm{Hb}}\end{array}$ & $\begin{array}{l}105.9(23.6) \\
105.4(23.6)\end{array}$ & $\begin{array}{l}103.2(20 \cdot 7) \\
103.0(20.8)\end{array}$ & $\begin{array}{l}113.8(17 \cdot 1) \\
113.7(15.6)\end{array}$ & $\begin{array}{l}96 \cdot 8(20 \cdot 6) \\
97 \cdot 1(20 \cdot 6)\end{array}$ & $\begin{array}{l}92 \cdot 7(48 \cdot 3) \\
92 \cdot 5(47 \cdot 8)\end{array}$ & $\begin{array}{l}92.0(35.9) \\
91.8(35.9)\end{array}$ & $\begin{array}{l}107 \cdot 4(26 \cdot 2) \\
107 \cdot 5(26 \cdot 2)\end{array}$ & $\begin{array}{l}99 \cdot 5(14 \cdot 6) \\
99 \cdot 4(15 \cdot 1)\end{array}$ \\
\hline
\end{tabular}

${ }^{\star} \mathrm{Cr}^{+6}, \mathrm{Cr}^{+3}$, and chromite groups $v$ control group, Student's two tailed $t$ test. $\mathrm{FVC}=\mathrm{FEV}, \mathrm{FVC} \times 100 ; \mathrm{PEF}=$ peak expiratory flow; $\mathrm{MEF}{ }_{50}=\mathrm{maximum}$ expiratory flow rate at $50 \%$ of the vital capacity; TLCO = diffusing capacity; TLCO capacity; $\mathrm{TLCO} / \mathrm{VA}_{\mathrm{Hb}}=$ specific diffusing capacity adjusted to haemoglobin.

†Smokers group includes both current and ex-smokers.

of most of the respiratory symptoms. Earlier allergic diseases were associated with the occurrence of shortness of breath (dyspnoea).

\section{LUNG FUNCTION TESTS}

In general the smokers showed lower lung function results. The smokers in the chromite group had significantly lower $\mathrm{FVC}, \mathrm{FEV}_{1}$, and diffusing capacity values than the smokers in the control group. The results of the lung function tests (as a percentage of the predicted values) of the $\mathrm{Cr}^{+6}$ and $\mathrm{Cr}^{+3}$ groups did not dif-

Table 5 Prevalence of impaired $\neq$ lung function test results

\begin{tabular}{|c|c|c|c|c|}
\hline $\begin{array}{l}\text { Lung function } \\
\text { variable }\end{array}$ & $\begin{array}{l}C r^{+6} \text { groupt } \\
(n=109) \\
\%\end{array}$ & $\begin{array}{l}C r^{+3} \text { groupt } \\
(n=76) \\
\%\end{array}$ & $\begin{array}{l}\text { Chromite groupt } \\
(n=36) \\
\%\end{array}$ & $\begin{array}{l}\text { Control groupt } \\
(n=95) \\
\%\end{array}$ \\
\hline FVC & $10 \cdot 0$ & $16 \cdot 0$ & $33 \cdot 3^{\star \star}$ & $10 \cdot 5$ \\
\hline $\mathrm{FEV}_{1}$ & $11 \cdot 8$ & $22 \cdot 7$ & $36 \cdot 1^{\star \star}$ & 13.7 \\
\hline FEV\% & 10.9 & $6 \cdot 7$ & $13 \cdot 9$ & $6 \cdot 3$ \\
\hline PEF & $0 \cdot 9^{\star}$ & $5 \cdot 3$ & $5 \cdot 6$ & $6 \cdot 3$ \\
\hline $\mathrm{MEF}_{50}$ & $12 \cdot 7$ & $17 \cdot 3$ & $27 \cdot 8$ & 13.7 \\
\hline $\mathrm{MEF}_{25}$ & $13 \cdot 6$ & $10 \cdot 7$ & $27 \cdot 8$ & $10 \cdot 5$ \\
\hline TLCO & $5 \cdot 5$ & $6 \cdot 7$ & $16 \cdot 7^{\star \star}$ & $2 \cdot 1$ \\
\hline $\operatorname{TLCO}_{\mathrm{Hb}}$ & $6 \cdot 4$ & $5 \cdot 3$ & $16 \cdot 7^{\star \star}$ & $2 \cdot 1$ \\
\hline TLCO/VA & $4 \cdot 6$ & $4 \cdot 0$ & $13 \cdot 9^{\star}$ & $3 \cdot 2$ \\
\hline $\mathrm{TLCO} / \mathrm{VA}_{\mathrm{Hb}}$ & $5 \cdot 5$ & $5 \cdot 3$ & $13 \cdot 9^{\star}$ & $3 \cdot 2$ \\
\hline
\end{tabular}

${ }^{\star} \mathrm{P}<0.05 ;{ }^{\star \star} \mathrm{P}<0.01\left(\mathrm{Cr}^{+6}, \mathrm{Cr}^{+3}\right.$, and chromite groups $v$ the control group, Student's two tailed $t$ test.)

tSmokers and non-smokers combined.

$\$$ Value lower than the 5 th percentile of distribution of the variable for adult non-smoking Finnish men. ${ }^{16}$

For abbreviations, see table 4

Table 6 Occurrence of small opacities (profusion $\geqslant 0 / 1$ ) by age

\begin{tabular}{lllll}
\hline Age group & $\begin{array}{l}\text { Cr } r^{+6} \text { group } \\
(n=109) \\
n(\%)\end{array}$ & $\begin{array}{l}\text { Cr }{ }^{+3} \text { group } \\
(n=76)\end{array}$ & $\begin{array}{l}\text { Chromite group } \\
(n=36) \\
n(\%)\end{array}$ & $\begin{array}{l}\text { Control group } \\
(n=95) \\
n(\%)\end{array}$ \\
\hline $29-44$ & $5(8 \cdot 2)$ & $1(3 \cdot 0)$ & $7(38 \cdot 9)$ & $6(8 \cdot 5)$ \\
$45-54$ & $7(16 \cdot 3)$ & $8(23 \cdot 5)$ & $2(13 \cdot 3)$ & $4(21 \cdot 1)$ \\
$55-65$ & $1(20 \cdot 0)$ & $5(55 \cdot 6)$ & $3(100 \cdot 0)$ & $2(50 \cdot 0)$ \\
Total & $(12 \cdot 0)$ & $(18 \cdot 4)$ & $(33 \cdot 3)$ & $(12 \cdot 8)$ \\
\hline
\end{tabular}

Table 7 Occurrence of small opacities

\begin{tabular}{lcccc}
\hline Profusion & $\begin{array}{l}\text { Cr } \\
(n=109)\end{array}$ & $\begin{array}{l}\text { Croup } \\
(n=76) \\
n(\%)\end{array}$ & $\begin{array}{l}\text { Chromite group } \\
(n=36) \\
n(\%)\end{array}$ & $\begin{array}{l}\text { Control group } \\
(n=95) \\
n(\%)\end{array}$ \\
\hline $0 / 1$ & $6(5 \cdot 5)$ & $4(5 \cdot 2)$ & $8(22 \cdot 2)$ & $11(11 \cdot 7)$ \\
$1 / 0$ & $4(3 \cdot 7)$ & $5(6 \cdot 6)$ & $2(5 \cdot 5)$ & $1(1 \cdot 1)$ \\
$1 / 1$ & $3(2 \cdot 8)$ & $5(6 \cdot 6)$ & $1(2 \cdot 8)$ & $0(0)$ \\
$1 / 2$ & $0(0)$ & $0(0)$ & $1(2 \cdot 8)$ & $0(0)$ \\
Total & $13(12 \cdot 0)$ & $14(18 \cdot 4)$ & $12(33 \cdot 3)$ & $12(12 \cdot 8)$ \\
\hline
\end{tabular}

${ }^{\star}$ Classified according to the more severe finding when the interpretations of the two radiologists differed from each other. fer from the corresponding results of the controls, except for the FVC of the smokers in the $\mathrm{Cr}^{+3}$ group, for whom it was lower than for the smokers in the control group (table 4).

In the group comparison of the adjusted lung function results, modelling for interactions between study group, smoking, and exposure time did not show a significant difference for any of the lung function variables.

The same analysis of variance without interactions showed that the chromite group had lower FVC, $\mathrm{FEV}_{1}$, and diffusing capacity values than the other groups, including the control group. The difference in these variables remained when smoking (pack-years) was included as a covariate in the model. The inclusion of smoking or pack-years or both significantly decreased the values of the same variables.

The percentages of the lung function test results that were below the predicted values ${ }^{16}$ were similar among the exposed groups, except for the chromite group, for which all the diffusing capacity variables and the FVC, $\mathrm{FEV}_{1}$, and $\mathrm{MEF}_{50}$ were significantly decreased (table 5).

\section{RADIOGRAPHS}

Table 6 shows the radiological findings. The number of positive findings increased with age in the $\mathrm{Cr}^{+6}, \mathrm{Cr}^{+3}$, and control groups.

Radiographic parenchymal abnormalities were found more often, but not significantly among the workers in the chromite group (table 7).

Changes in the parietal and visceral pleura were also more frequent (not significantly) among the workers exposed to chromite, who, however, had no bilateral plaques (table 8 ).

URINARY CHROMIUM

The mean urinary concentration of chromium was $0.03 \mu \mathrm{mol} / 1$ for the 44 workers in the steel smelting shop $(0.04 \mu \mathrm{mol} / 1$ in the previous study in $\left.1987^{12}\right)$. The maximum concentration was $0.08 \mu \mathrm{mol} / 1(0.34 \mu \mathrm{mol} / 1$ in 1987$)$. The results of these control measurements indicate that the level of chromium exposure in 1993 was the same or slightly lower than in 1987. ${ }^{12}$ 
Table 8 Pleural plaques and changes in the visceral pleura

\begin{tabular}{|c|c|c|c|c|}
\hline Variable & $\begin{array}{l}\text { Cr.6 group } \\
(n=109) \\
n(\%)\end{array}$ & $\begin{array}{l}\mathrm{Cr}^{-3} \text { group } \\
(n=76) \\
n(\%)\end{array}$ & $\begin{array}{l}\text { Chromite group } \\
(n=36) \\
n(\%)\end{array}$ & $\begin{array}{l}\text { Control group } \\
(n=95) \\
n(\%)\end{array}$ \\
\hline $\begin{array}{l}\text { Bilateral pleural plaques } \\
\text { Unilateral pleural plaques } \\
\text { Changes in visceral pleura }\end{array}$ & $\begin{array}{l}5(4 \cdot 6) \\
5(4 \cdot 6) \\
1(0 \cdot 9)\end{array}$ & $\begin{array}{l}2(2 \cdot 6) \\
1(1 \cdot 3) \\
1(1 \cdot 3)\end{array}$ & $\begin{array}{l}\overline{4}(11 \cdot 1) \\
2(5 \cdot 6)\end{array}$ & $\begin{array}{l}\overline{3}(3 \cdot 2) \\
1(1 \cdot 1)\end{array}$ \\
\hline
\end{tabular}

${ }^{\star}$ Costophrenic angle obliteration or pleural adhesions or thickening of the visceral pleura.

Table 9 Description of chromium compounds ${ }^{20}$

\begin{tabular}{ll}
\hline Chromite & Chromium ore $\left(\mathrm{Cr}_{2} \mathrm{FeO}_{4}\right), \mathrm{Cr}^{+3}$ \\
Ferrochromium & Chromium alloy $(\mathrm{Cr}, \mathrm{C}, \mathrm{Fe}, \mathrm{N}, \mathrm{Si}), \mathrm{Cr}^{0}$ \\
Chromates & Salts of chromic acid $\left(\mathrm{H}_{2} \mathrm{CrO}_{4}\right), \mathrm{Cr}{ }^{\circ}$ \\
Chromium & Metallic chromium $(\mathrm{Cr}), \mathrm{Cr}^{\circ}$ \\
\hline
\end{tabular}

FORMER WORKERS

The questionnaire was returned by 37 former workers $(70 \%)$. They reported that they had experienced the following symptoms during the years they were working for the company: frequent cough $(16 \cdot 2 \%)$, production of phlegm $(16 \cdot 2 \%)$, shortness of breath $(13 \cdot 5 \%)$, rhinitis $(35 \cdot 1 \%)$, eye irritation $(8 \cdot 1 \%)$, dermatitis $(18.9 \%)$, and various symptoms (headache, vertigo, fatigue, etc, $16 \cdot 2 \%$ ).

None of the former workers reported that a disease had been a reason for leaving the company. At the time of the survey one person $(2 \cdot 7 \%)$ reported having chronic bronchitis and two people $(5.4 \%)$ reported bronchial asthma. No other pulmonary diseases, allergic rhinitis, or cancer were reported.

\section{Discussion}

The respiratory effects of exposure to chromium compounds have been studied in various industries, but none of the studies cover the entire production chain of stainless steel. Because our objective was to study chronic effects, the requirement for a minimum duration of employment had to be kept high. Therefore the group sizes were small. This will decrease the statistical power of the study, as can be seen in the wide $95 \%$ confidence intervals (95\% CIs) of the ORs for symptoms (table 3 ). On the other hand, the durations of exposure were long, the average ranging from 16 to 20 years in the different exposure groups. Lowering the durations of exposure would not have essentially increased the group sizes.

Most of the workers in this study had worked in the same production department during their entire employment at Outokumpu Oy. Therefore the exposures can be considered to be the same for all the people in any given department, occasional peaks being smoothed by time. Thus the scarcity of findings in this study is not due to the possibility that the pathological findings of a small, but highly exposed group had been diluted among a larger and less exposed group.

All the workers who had already left the company received a questionnaire, and $70 \%$ of them returned it. Half of the $70 \%$ had smoked while employed by the company. This group of former workers did not differ from the other groups for respiratory symptoms. Chronic bronchitis among the former workers was as rare as among the workers examined. Two former workers reported bronchial asthma, but none of the present workers did. None of the former workers reported a disease as a reason for leaving the company. Thus selection can be regarded as non-existent in this study.

The lung function tests could not be carried out in a randomised order for practical reasons. However, the lack of randomisation cannot be considered to have had any notable effect on the results because the tests were performed in a standardised manner.

Minor differences in the occurrence of cough and shortness of breath were seen when the $\mathrm{Cr}^{+6}, \mathrm{Cr}^{+3}$, and chromite groups were compared with the control group. However, in the logistic regression analysis no significant differences in the risk ratios were found between the groups.

The lung function results of our study could not be compared with the results from other studies because there are no such data available on stainless steel production.

As in this study epidemiological studies on respiratory functions very often indicate that the results of lung function tests of former smokers may surprisingly differ from the results of both non-smokers and current smokers. The reason for them having stopped smoking is often some effect on the respiratory system. Therefore in this study ex-smokers were included in the group of smokers in most of the analyses.

The results of the lung function tests in the groups exposed to $\mathrm{Cr}^{+6}$ or $\mathrm{Cr}^{+3}$ did not differ from those of the control group. On the contrary, the results on respiratory volumes and diffusing capacity in the chromite group were slightly worse than those of the control group. This difference was most evident for the smokers in this group, which had the largest proportion of smokers.

The airborne dust in the chromite mine has been shown to be one third chromite, one third talc, and one third chlorite serpentine. The talc and serpentine particles are primarily lamellar schists. Part of the chlorite serpentine particles can be classified as fibres. During the late 1960s and early 1970s, when the process was different and the technology less advanced, the dust concentrations in the ambient air at the mine were higher than the current concentrations.

Limited areas in the ore of the north eastern part of the mine and its waste rock contained crevices filled with chrysotile. During 1987-9 the mean concentration of fibres in personal samples was 0.14 fibres $/ \mathrm{cm}^{3}$ for drillers and $0.11 \mathrm{fibres} / \mathrm{cm}^{3}$ for loaders at the open pit and $0.28 \mathrm{fibres} / \mathrm{cm}^{3}$ in the concentrating plant. According to scanning electron microscopy $42.5 \%$ of these fibres were chrysotile asbestos, and the rest comprised other particles-for example, vertical lamellar minerals.

The workers from the chromite mine were slightly older than the controls, and the proportion of smokers among them was greater. Therefore the lower lung function values of 
these workers can be explained partly, but not totally, by the differences in age and smoking habits between the groups. It is also probable that there is a causal correlation between our findings and both the higher dust exposures during the first years of mine operation and the fibrous minerals in the waste rock of the mine.

Radiological parenchymal abnormalities and plaques classified according to ILO recommendations were not common in our study. Small opacities were more frequently observed in the radiographs of the workers exposed to chromite than in the radiographs of the other groups. This finding agrees with the idea that early exposure to fibrous materials is a factor contributing to the pulmonary effects.

An increased risk of lung cancer has been found among workers in the production of chromates and chromate pigments, as well as in chromium plating, although no conclusive data are available on lung cancer in ferrochromium production..$^{20}$ No cases of lung cancer were found in this study. However, risk of cancer could not be excluded because the follow up time was short and the exposed group young and small.

No cases of chromium asthma were found in this study. It was recently reported that mortality from non-malignant diseases of the respiratory system was not increased (standardised mortality ratio (SMR 0.88)) among production workers in stainless steel production. ${ }^{21}$

\section{Conclusions}

An average exposure time of 18 years in modern ferrochromium and stainless steel production and low exposure to dusts containing $\mathrm{Cr}^{+6}$ or $\mathrm{Cr}^{+3}$ does not lead to any respiratory changes detectable by lung function tests or radiography or to any increase in symptoms of respiratory diseases. The process chain under study is unique; however, the results are also applicable to other production facilities where the exposures to different chromium compounds are equally low.

The lung function test results were lower and the occurrence of radiological findings was more frequent among the workers from the chromium mine than among the controls. The difference was partly caused by differences in age and smoking habits, but evidently also partly by higher exposures more than two decades ago, when the mine operations were started, and by the fibrous components of the dust.

Because the follow up time was limited, we are planning a reinvestigation after five years, although there are no personal needs or expected benefits to individual workers. The main reason is to collect new information and to confirm the present results.

This study was conducted with financial support from the Finnish Work Environment Fund.

1 Meyers JB. Acute pulmonary complications following inhalations of chromic acid mist. Arch Ind Hyg Occup inhalations of chromic
Med 1950:2:742-7.

2 Haines AT, Nieboer E. Chromium hypersensitivity. In: Nriagu JO, Nieboer E, eds. Chromium in the natural and human environments. New York: John Wiley, 1988 497-532.

3 Ballal SG. Respiratory symptoms and occupational bronchitis in chromite ore miners, Sudan. Fournal of Tropical Medicine and Hygiene 1986;5:223-8.

4 Reggiani A, Lotti M, De Rosa E, Saia B. Impairments of respiratory functions in subjects exposed to chromium: Note 1. Spirographic changes. Lavoro Umano 1973;25: 23-7.

5 Bovet P, Lob M, Grandjean M. Spirometric alterations in workers in the chromium electroplating industry. Int Arch Occup Environ Health 1977;40:25-32.

6 Lindberg E, Hedenstierna G. Chrome plating: symptoms, findings in the upper airways, and effects on lung function. Arch Environ Health 1983;38:367-74.

7 Langård S. A survey of respiratory symptoms and lung function in ferrochromium and ferrosilicon workers. In Arch Occup Environ Health 1980;46:1-9.

8 Mancuso TF, Hueper WC. Occupational cancer and other health hazards in a chromate plant: a medical appraisal. I. Lung cancer in chromate workers. Ind Med Surg 1951; 20:358-63.

9 Zober A. Possible dangers to the respiratory tract from welding fumes: methods of approach in an industrial health care context and results. Schweissen Schneiden 1982;34:77-81.

10 US Public Health Service. Health of workers in chromate producing industry. Washington, DC: US Department of ducing industry. Washington, DC: US Department of Health, Education, and

11 Swensson A. Experimental research on the fibrogenetic effect of chromite. Stockholm: Arbetarskyddsverket 1977. Arbete och Hälsa 1977;2:1-14.

12 Huvinen M, Kiilunen M, Oksanen L, Koponen M, Aitio A Exposure to chromium and its evaluation by biological monitoring in the production of stainless steel. Occup Med Toxicol 1993;3:205-16.

13 Love RG, Smith TA, Gurr D, Soutar CA, Scarisbrick DA Seaton A. Respiratory and allergic symptoms in wool textile workers. $B r f$ Ind $M e d$ 1988;45:727-41.

14 Medical Research Council (MRC). Questionnaire on respiratory symptoms, instructions to interviewers. London: MRC, tory symp 1986.

15 American Thoracic Society. Standardization of spirometry (1987) update. Am Rev Respir Dis 1987;136:1285-98.

16 Viljanen AA, Halttunen PK, Kreus K-E, Viljanen BC Reference values for spirometric, pulmonary diffusing capacity and body plethysmographic studies. Scand $\mathcal{F}$ Clin Lab Invest 1982;42(suppl 159):1-50.

17 Make B, Miller A, Epler G, Gee JBL. Single breath diffusing capacity in the industrial setting. Chest 1982;82:351-6.

18 Cotes JE. Lung function. Assessment and application in medicine. 3rd ed. Oxford: Blackwell, 1975.

19 International Labour Office. International classification of radiographs of pneumoconioses. Geneva: ILO, 1980.

20 International Agency for Research on Cancer. IARC monographs on the evaluation of carcinogenic risks to humans. Vol 49. Lyon: IARC, 1990.

21 Moulin J, Wild P, Mantout B, Fournier-Betz M, Mur JM, Smagghe G. Mortality from lung cancer and cardiovascular diseases among stainless-steel producing workers Cancer Causes Control. 1993;4:75-81.

\section{Rejected manuscripts}

From February 1994, authors whose submitted articles are rejected will be advised of the decision and one copy of the article, together with any reviewers' comments, will be returned to them. The fournal will destroy remaining copies of the article but correspondence and reviewers' comments will be kept. 